\title{
Microsatellite Instability in the Adenoma-Carcinoma Sequence of the Stomach
}

\author{
Hee Sung Kim, Dong-Kyun Woo, Soo In Bae, Yong II Kim, and Woo Ho Kim \\ Department of Pathology (HSK, SIB, YIK, WHK), and Cancer Research Center (D-KW, WHK), Seoul National \\ University College of Medicine, Seoul, Korea
}

\begin{abstract}
SUMMARY: Sixty-three cases of stomach resections harboring both adenoma and carcinoma were analyzed for microsatellite instability (MSI). The cases included 28 carcinomas arising from adenoma (Type I) and 35 carcinomas with separate adenoma (Type II). The results of MSI assessed by 49 markers were the same for BAT-26 instability. The incidence of MSI was $21 \%$ in gastric adenoma and $30 \%$ in gastric carcinoma, which is significantly higher than gastric carcinoma without associated adenoma $(p<0.01)$. Five of eight $(63 \%)$ cases of multiple carcinomas associated with adenoma showed MSI+ in adenoma and in one or more carcinoma lesion(s). Eight of thirteen (62\%) MSI+ adenomas were associated with carcinoma, whereas 20 of 50 (40\%) MSI- adenomas were associated with carcinoma. MSI+ adenomas of Type I showed a higher mutation rate of the TGF- $\beta$ RII gene than Type II (88\% versus $40 \%$ ). Gastric adenoma with TGF- $\beta$ RII gene mutation was more prone to transform into carcinoma $(p=0.03)$. This study revealed that gastric carcinoma arising from adenoma is frequently associated with a mismatch repair deficiency mechanism. In the gastric adenoma-carcinoma sequence, TGF- $\beta$ RIl gene mutation occurred early in the adenoma stage and it persisted after malignant transformation. (Lab Invest 2000, 80:57-64).
\end{abstract}

$\mathcal{G}$ astric adenoma is a precancerous lesion, $11 \%$ to $40 \%$ of which transforms into carcinoma (Kamiya et al, 1982; Ming and Goldman, 1965). The intestinal type of gastric carcinoma is different from the diffuse type in patterns of histopathology and genetic alterations. The former is generally derived from the adenoma-carcinoma sequence in stomach carcinogenesis (Semba et al, 1996) and might develop through a cumulative series of gene alterations similar to that of colorectal cancer (Tahara, 1995).

The form of genomic instability associated with defective DNA mismatch repair in tumors is called microsatellite instability (MSI). Much confusion and many conflicting concepts regarding MSI were resolved after a workshop sponsored by the (US) National Cancer Institute (Boland et al, 1998). During the workshop, MSI-H was defined as a cancer demonstrating $\mathrm{MSI}$ in $40 \%$ of the markers. The remaining cases consisted of either MSI-L cases (MSI in less than $40 \%$ of the markers) or MSS cases (MSI in none of the markers). Clinicopathologic data revealed that MSS and MSI-L belong to the same group, but that $\mathrm{MSI}-\mathrm{H}$ is a different entity. Although the workshop analyzed the results of colorectal carcinoma, subsequent studies proved that the definition of MSI could be applied in the same way to other carcinomas, such as gastric, endometrial, or biliary.

Received September 21, 1999.

This study was supported by a grant (\#HMP-99-M-03-0001) from the '99 Good Health ReD Project, Ministry of Health and Welfare, Korea. Address reprint requests to: Dr. Woo Ho Kim, Department of Pathology, Seoul National University College of Medicine, 28 Yongon-dong, Chongno-gu, Seoul 110-799, Korea. Fax: 82-2-765-5600; E-mail: woohokim@snu.ac.kr
At least six human genes involved in the mismatch repair have been identified ( $h M S H 2, h M S H 3, h M S H 6$, $h M L H 1, h P M S 1$, and hPSM2). Among them, aberrant methylation of the $h M L H 1$ gene promoter has been proven to be the major cause of $\mathrm{MSI}$ in sporadic colorectal carcinoma (Kane et al, 1997), and similar results have been demonstrated in gastric carcinoma (Leung et al, 1999). The mechanism by which MSI contributes to cancer has been assumed to be a mismatch repair deficiency that results in mutations of cancer-related genes. Such mutations are thought to be responsible for carcinogenesis or tumor progression, or both (Arnheim and Shibata, 1997). Known target molecules affected by mismatch repair deficiency include the transforming growth factor- $\beta$ receptor Type II (TGF- $\beta$ RII) gene (Chung et al, 1996, 1997; Markowitz et al, 1995; Myeroff et al, 1995), the IGFIIR gene (Chung et al, 1997; Ouyang et al, 1997; Souza et al, 1996), and the BAX gene (Chung et al, 1997; Rampino et al, 1997).

To study $\mathrm{MSI}$ and frameshift mutations of target genes in the gastric adenoma-carcinoma sequence, we retrieved 63 cases of stomach resections that harbored adenomas and carcinomas simultaneously, and analyzed them for MSI and mutations at coding mononucleotide repeats. Our results suggest that gastric carcinoma arising from the adenomacarcinoma sequence showed a higher frequency of $\mathrm{MSI}$ and is frequently associated with frameshift mutation of the TGF- $\beta$ Rll gene.

\section{Results}

Sixty-three cases of primary gastric carcinoma with coexisting adenoma were retrospectively identified 


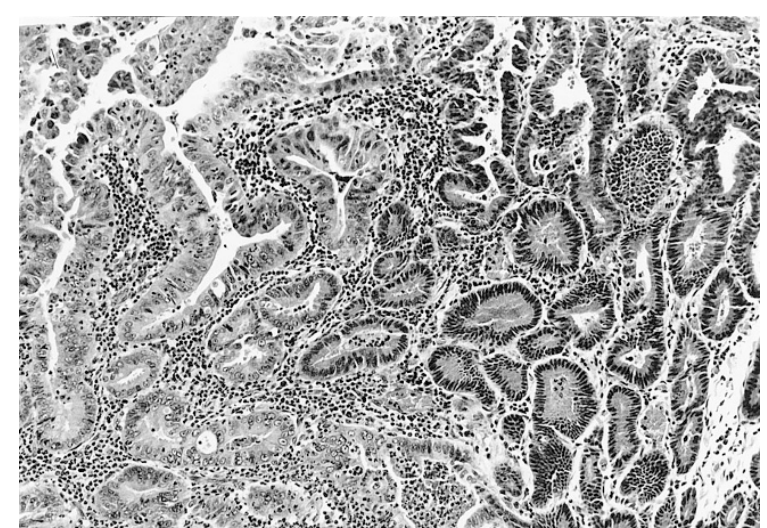

Figure 1.

Histopathology of Type I gastric adenoma with carcinomatous transformation (Case B5). Intestinal type adenocarcinoma (left) is surrounded by adenoma (right) (original magnification $\times 100$, hematoxylin and eosin $[\mathrm{HE}]$ ).

from the surgical pathology files of Seoul National University Hospital for this study. Pathologic slides were reviewed to analyze pathologic parameters, including tumor size, gross type, intestinal metaplasia of adjacent mucosa, and depth of invasion of the carcinoma. The carcinomas were classified histologically according to the World Health Organization classifications (Watanabe et al, 1990), Lauren (1965) and Ming (1977), and staged according to the criteria of the International Union Against Cancer (UICC) (1997). The adenomas consisted of 7 polypoid, 41 elevated, 10 flat, and 5 depressed types; 39 tubular, 17 tubulovil- lous, and 7 villous types; 63 intestinal types and no gastric types; and 22 high-grade and 41 low-grade adenomas. The carcinomas consisted of 43 early gastric carcinomas and 20 advanced gastric carcinomas; 44 intestinal types, 12 diffuse types, and 7 mixed types.

We classified these cases into two categories according to the association between carcinoma and adenoma. Type I was defined as carcinoma found directly adjacent to adenoma or admixed with adenoma (Fig. 1). Type II denoted cases in which carcinoma was located separately from adenoma. Type I provided the model for the gastric adenomacarcinoma sequence and demonstrated significant associations with $\mathrm{T} 1$ stage, intestinal type, antral location, expanding growth, and histologically highgrade adenoma when compared to Type II (Table 1).

\section{Assessment of MSI}

We analyzed the MSI status using 49 microsatellite markers and BAT-26 marker on 60 lesions from 30 cases. Fifteen samples showed high-frequency $\mathrm{MSI}$ (MSI-H or MSI in $40 \%$ or more of the tested markers), 43 samples showed low-frequency MSI (MSI-L or MSI in less than $40 \%$ of the tested markers), and 2 samples did not show alteration in any marker (microsatellite stable or MSS). When we compared these results with the alteration of the BAT-26 marker, all of the MSI-H lesions showed a positive alteration on the BAT-26 marker, regardless of adenoma or carcinoma in both Type I and II (Fig. 2). However, none of the

Table 1. Clinicopathologic Profiles of Gastric Carcinomas Associated with Adenomas Analyzed for MSI

\begin{tabular}{|c|c|c|c|c|}
\hline & $\begin{array}{c}\text { Type } \mathrm{I}^{a} \\
(n=28)\end{array}$ & $\begin{array}{l}\text { Type II } \\
(n=35)\end{array}$ & $\begin{array}{c}\text { Total } \\
(n=63)\end{array}$ & $p$ value \\
\hline Mean age of patient & $61.4 \pm 7.1$ & $59.3 \pm 8.8$ & $60.2 \pm 8.1$ & NS \\
\hline Ratio male:female & $3.7: 1$ & 4.8:1 & 4.3:1 & NS \\
\hline Location of carcinoma & & & & 0.24 \\
\hline Cardia \& body & 11 & 19 & 30 & \\
\hline Antrum & 17 & 16 & 33 & \\
\hline Size of carcinoma & $4.3 \pm 2.2$ & $4.4 \pm 2.6$ & $4.3 \pm 2.4$ & NS \\
\hline Ming & & & & $<0.01$ \\
\hline Expanding & 28 & 18 & 46 & \\
\hline Infiltrative & 0 & 17 & 17 & \\
\hline Lauren & & & & 0.01 \\
\hline Intestinal & 25 & 19 & 44 & \\
\hline Diffuse & 2 & 10 & 12 & \\
\hline Mixed & 1 & 6 & 7 & \\
\hline Stage & & & & $<0.01$ \\
\hline $\mathrm{T} 1$ & 26 & 17 & 43 & \\
\hline$>\mathrm{T} 2$ & 2 & 18 & 20 & \\
\hline LN metastasis & & & & $<0.05$ \\
\hline Absent & 25 & 22 & 47 & \\
\hline Present & 3 & 13 & 16 & \\
\hline Adenoma grade & & & & $<0.05$ \\
\hline High & 14 & 8 & 22 & \\
\hline Low & 14 & 27 & 41 & \\
\hline
\end{tabular}

\footnotetext{
${ }^{a}$ Type I, carcinoma arising from adenoma.

${ }^{b}$ Type II, carcinoma with separate adenoma.
} 


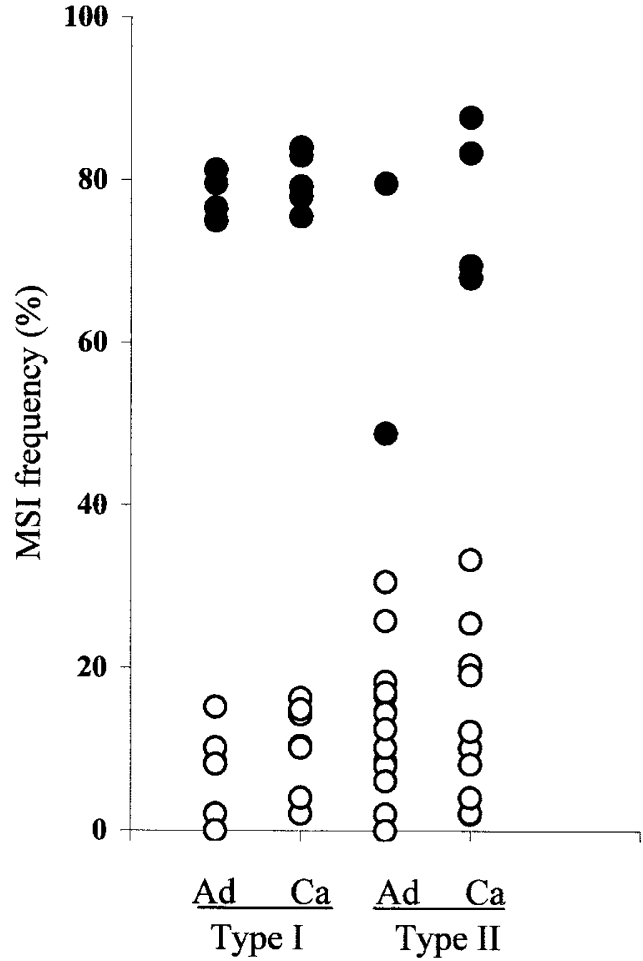

Figure 2.

Correlation between high-frequency MSI (MSI-H) and BAT-26 instability in four subgroups of adenoma and carcinoma of Type I and Type II. $\bigcirc$ BAT-26 stable; - BAT-26 unstable; Ad, adenoma; Ca, carcinoma. Fifteen samples with high-frequency MSI (MSI-H) are MSI+ in BAT-26. Forty-five samples showing low-frequency MSI (MSI-L) or microsatellite stable (MSS) are MSI- in BAT-26.

MSI-L or MSS lesions showed this alteration. This proved the high sensitivity and high specificity of the BAT-26 marker in predicting MSI-H tumors (Hoang et al, 1997; Zhou et al, 1998; Perucho, 1999). These results also proved that most MSS tumors would be categorized as MSI-L if we increased the number of tested markers. Based on these results, we evaluated the $\mathrm{MSI}$ status of the remaining 76 lesions from 33 patients using BAT-26 as an indicator of MSI-H. Accordingly, we designated the cases that showed alteration of BAT-26 marker as $\mathrm{MSI}+$ (Fig. 3). The rest of the cases were described as $\mathrm{MSI}-$, consisting of either MSI-L or MSS.

\section{MSI in Gastric Carcinoma and Adenoma}

Of the 63 cases, 13 of the adenomas (21\%) and 19 of the carcinomas $(30 \%)$ were $\mathrm{MSI}+$. The incidence of $\mathrm{MSI}+$ was higher in Type I adenoma than in Type II adenoma (29\% versus 14\%), and higher in Type I carcinoma than in Type II carcinoma (39\% versus 23\%) (Fig. 4). Eight cases of Type I adenoma were $\mathrm{MSI}+$, and of those cases, all carcinomas were also $\mathrm{MSI}+$. In three cases of Type I, the carcinoma lesions were $\mathrm{MSI}+$, whereas the adenoma lesions were $\mathrm{MSI}-$. In contrast, only 3 of the 35 Type II cases were $\mathrm{MSI}+$ in both the adenoma and carcinoma (Table 2). It is obvious that MSI is a phenomenon that is main- tained during the adenoma-carcinoma sequence, and that $\mathrm{MSI}$ could develop during the carcinomatous transformation step. The MSI+ carcinomas were associated with an antral location $(p<0.01)$, expanding growth, intestinal type, T1 stage, and no lymph node metastases. However, no significant association was found between $\mathrm{MSI}+$ adenoma and size, histologic type, histologic grade, residual intestinal metaplasia, or location (data not shown).

\section{Frameshift-Mutations in the Coding Regions}

No mutations were identified in the MSI- cases in any of the examined genes. We observed frameshift mutations in the poly $(\mathrm{A})_{10}$ tract of TGF- $\beta$ RII gene in 9 $(69 \%)$ of the $\mathrm{MSI}+$ adenomas and $17(90 \%)$ of the $\mathrm{MSI}+$ carcinomas. The incidence of TGF- $\beta$ RIl gene mutation in Type I adenoma was significantly higher than in Type II adenoma (Fig. 4). This suggested that adenoma with TGF- $\beta$ RII gene mutation is frequently associated with malignant transformation. Two adenomas of Type II with TGF- $\beta$ RII gene mutation were 1.3-cm low-grade villotubular adenoma (Case B8) and 0.5-cm low-grade tubular adenoma (Case B4).

Mutations were also found in the $\operatorname{poly}(\mathrm{G})_{8}$ tract of the $B A X$ gene in four (31\%) MSI+ adenomas and 13 (68\%) $\mathrm{MSI}+$ carcinomas. This suggested that $B A X$ gene mutation usually occurs later than TGF- $\beta$ RII mutation. Two (15\%) of the MSI+ adenomas and one $(5 \%)$ of the $\mathrm{MSI}+$ carcinomas showed frameshift mutations of the poly $(\mathrm{G})_{8}$ tract of the IGFIIR gene. Mutation of the poly $(\mathrm{A})_{8}$ tract of the $h M S H 3$ gene was found in five (39\%) MSI+ adenomas and six (33\%) $\mathrm{MSI}+$ carcinomas.

Mutations involved deletion of one or two bases in TGF- $\beta$ RII; deletion or addition of one base in BAX; deletion of one base or addition of two bases in IGFIIR; and deletion of one base in $h M S H 3$ genes (Fig. 5). In the adenoma-carcinoma sequence, the mutation pattern was usually preserved (Table 2).

Most of the mutations in the polytract genes were found within the cases with a mutated TGF- $\beta$ RII gene. Only three samples showed mutations of other polytract genes without TGF- $\beta$ RII gene mutation: one case of Type I carcinoma (Case 22) and two cases of Type II adenoma (Case 30, B10).

\section{Analysis of Multiple Carcinomas Associated with Adenoma}

Of 63 cases, eight had more than one carcinoma lesion; of those, five (63\%) cases showed $\mathrm{MSI}+$ in adenoma and in one or more carcinoma lesion(s). The incidence of $\mathrm{MSI}+$ in cases with multiple carcinoma was higher than in cases with a single carcinoma, both in the carcinoma and the associated adenoma ( $p<$ 0.05) (Fig. 4). All three cases of Type I with multiple carcinomas were $\mathrm{MSI}+$ in both adenoma and carcinomas.

Two cases exhibited different MSI status between the multiple carcinomas, but three cases showed co-occurrence of MSI in multiple carcinomas. Of nine 


\section{BAT-26}

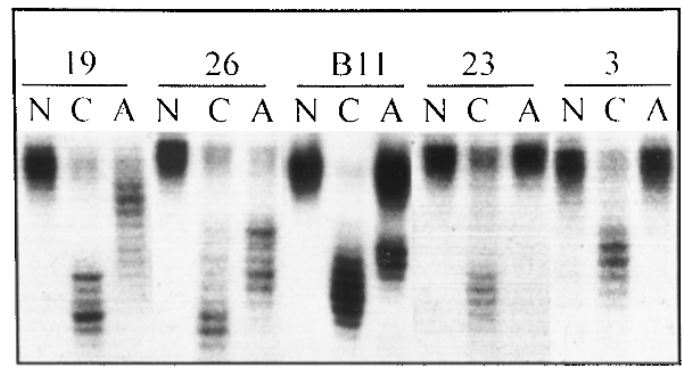

Figure 3.

Examples of $B A T-26$ alteration. Adenoma or carcinoma with size variation in the BAT-26 allele is defined as MSI+. N, normal; C, carcinoma; A, adenoma; Cases 19, 26, and B11 (Type I) were MSI+ in both adenoma and carcinoma. Case 23 (Type I) and Case 3 (Type II) were MSI+ in carcinoma and MSI- in adenoma.

$\mathrm{MSI}+$ carcinoma lesions, TGF- $\beta$ RII gene mutations were seen in seven (78\%), BAX gene mutation in five, IGFIIR gene mutation in two, and $h M S H 3$ genes mutation in five (Table 3). All of the samples of one adenoma and two carcinomas from Case B8 showed mutations in all four examined genes. However, the mutation patterns of the $B A X$ gene in the adenoma and carcinoma were slightly different.

\section{Discussion}

The $\mathrm{MSI}+$ rate in gastric cancer among Koreans without co-occurrence of adenoma is approximately $10 \%$ (Kang et al, 1999). This figure is not much different from most of the recent data on Japanese (14.6\%) (Yamamoto et al, 1999), Australians (9.9\%) or Caucasian people (8.5\%) (Halling et al, 1999). Our results on carcinoma arising from adenoma (Type I) showed an incidence of MSI+ that was 4 times the incidence in ordinary gastric cancer $(p<0.01)$. The above data suggest that gastric carcinoma arising from adenoma is more frequently associated with a mismatch repair-deficient carcinogenic pathway than de novo carcinoma. Furthermore, carcinoma with separate adenoma (Type II) showed an incidence of MSI+ 2 -fold higher than in cases without adenoma. The cause of this higher incidence might be related to the higher frequency of intestinal type in this category, but the exact cause should be studied. Although one
A
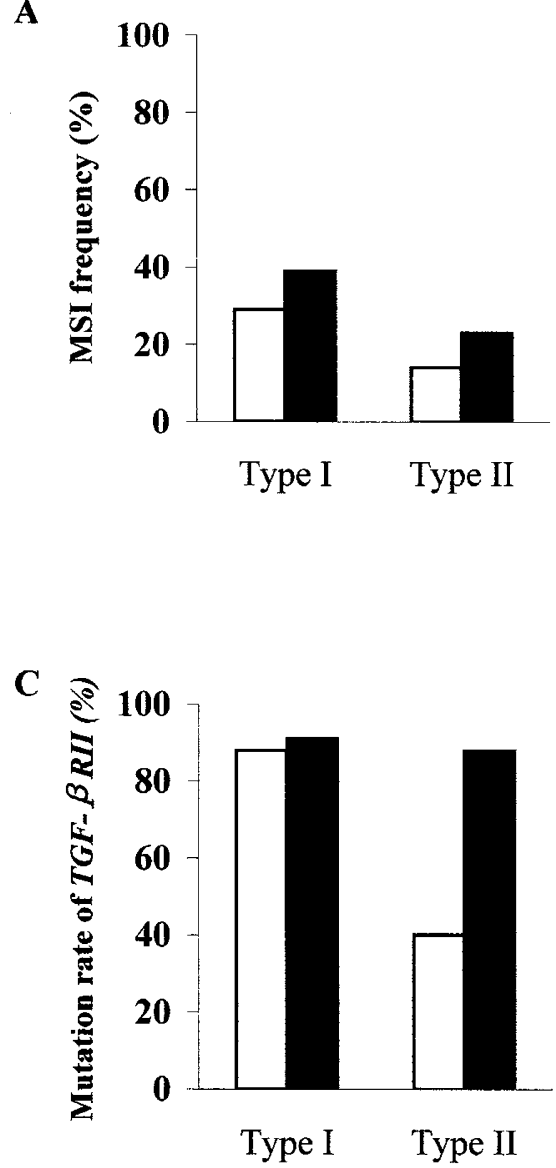

B

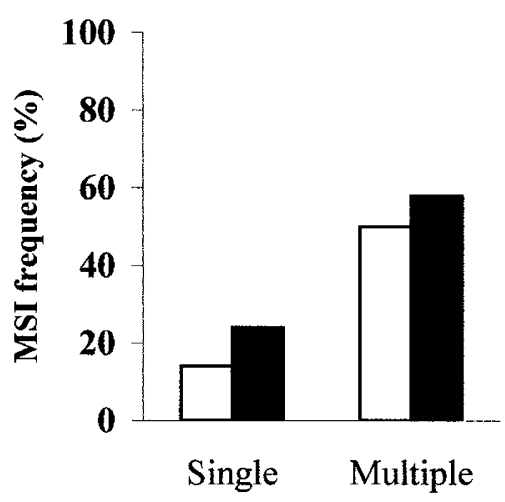

D

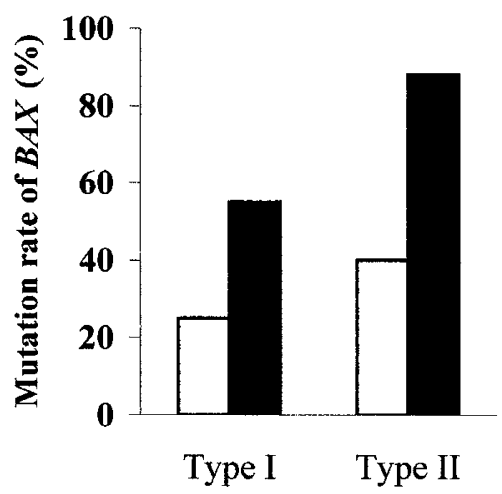

Figure 4.

Comparison of $\mathrm{MSI}+$ frequency and gene mutation rate in gastric adenoma and carcinoma; $\square$, adenoma and $\mathbf{\square}$, carcinoma. $A$, Type I adenoma and carcinoma showed higher $\mathrm{MSI}+$ incidence than those of Type II. B, MSI+ incidence is higher in the cases of multiple carcinomas associated with adenoma than cases of single carcinoma. C, TGF- $\beta$ RII gene mutation is more frequent in Type I adenoma and carcinoma than Type II. (D), BAX gene mutation is more frequent in carcinoma than in adenoma in both Type I and Type II. 
Table 2. Histopathologic Profiles, Status of MSI, and Coding Mononucleotide Repeats within the TGF- $\beta$ RII, BAX, IGFIIR, and hMSH3 genes in $21 \mathrm{MSI}+$ cases

\begin{tabular}{|c|c|c|c|c|c|c|c|c|c|c|c|c|c|c|}
\hline \multirow[b]{2}{*}{ Case } & \multirow[b]{2}{*}{ Stage } & \multirow[b]{2}{*}{ Location $^{a}$} & \multicolumn{2}{|c|}{ Adenoma } & \multirow{2}{*}{ Type $^{d}$} & \multirow{2}{*}{$\frac{\mathrm{MSI}^{e}}{\mathrm{Ad} \mathrm{Ca}}$} & \multicolumn{2}{|c|}{$\mathrm{TGF}-\beta \mathrm{R} \|^{f}$} & \multicolumn{2}{|c|}{$B A X^{f}$} & \multicolumn{2}{|c|}{ IGFIIR ${ }^{f}$} & \multicolumn{2}{|c|}{$\mathrm{hMSH}^{f}$} \\
\hline & & & Lauren $^{b}$ & Grade $^{c}$ & & & $\mathrm{Ad}$ & $\mathrm{Ca}$ & $\mathrm{Ad}$ & $\mathrm{Ca}$ & $\mathrm{Ad}$ & $\mathrm{Ca}$ & $\mathrm{Ad}$ & $\mathrm{Ca}$ \\
\hline 23 & T1 & B & I & $\mathrm{H}$ & I & 00 & - & $-1 /-2$ & - & $-1 / w t$ & - & - & - & - \\
\hline B30 & $\mathrm{T} 1$ & $A$ & I & $\mathrm{H}$ & I & 00 & - & $-1 / w t$ & - & $-1 / w t$ & - & - & - & - \\
\hline B31 & $\mathrm{T} 1$ & $A$ & i & $\mathrm{L}$ & I & 00 & - & $-1 /-2$ & - & - & - & - & - & nd \\
\hline 19 & $\mathrm{~T} 1$ & $A$ & I & $\mathrm{L}$ & I & 0 & $-1 / w t$ & $-1 / w t$ & - & - & - & - & $-1 / w t$ & $-1 / w t$ \\
\hline 20 & T3 & $A$ & $D$ & $\mathrm{~L}$ & I & 0 & $-1 / w t$ & $-1 / w t$ & $+1 / w t$ & $+1 / w t$ & - & - & - & - \\
\hline 22 & $\mathrm{~T} 2$ & $A$ & 1 & $\mathrm{~L}$ & I & 0 & $-1 / w t$ & - & - & $+1 / w t$ & - & - & - & $-1 / w t$ \\
\hline 26 & $\mathrm{~T} 1$ & B & I & $\mathrm{H}$ & I & 0 & $-1 / w t$ & $-1 / w t$ & $-1 / w t$ & - & - & - & $-1 / w t$ & - \\
\hline B11 & $\mathrm{T} 1$ & $A$ & I & $\mathrm{L}$ & I & 0 & - & $-1 / w t$ & - & $-1 / w t$ & - & - & - & - \\
\hline B19 & T1 & $A$ & I & $\mathrm{L}$ & I & 0 & $-1 /-2$ & $-1 /-2$ & - & - & - & - & - & - \\
\hline B20 & T1 & $A$ & I & $\mathrm{H}$ & I & 0 & $-1 / w t$ & $-1 / w t$ & - & - & - & - & - & - \\
\hline B24 & $\mathrm{T} 1$ & B & I & $\mathrm{H}$ & I & 0 & $-1 / w t$ & $-1 / w t$ & - & $-1 / w t$ & - & - & - & $-1 / w t$ \\
\hline 2 & T3 & B & $M$ & $\mathrm{H}$ & II & 0 & - & - & - & - & - & - & - & - \\
\hline B10 & $\mathrm{T} 1$ & $A$ & $D$ & $\mathrm{~L}$ & II & 0 & - & - & - & - & $+1 / w t$ & - & $-1 / w t$ & - \\
\hline 3 & $\mathrm{~T} 2$ & $A$ & $M$ & $\mathrm{H}$ & II & $\bigcirc 0$ & - & $-1 /-2$ & - & $+1 / w t$ & - & - & - & $-1 / w t$ \\
\hline 6 & $\mathrm{~T} 2$ & $A$ & $D$ & $\mathrm{~L}$ & II & $\bigcirc 0$ & - & $-1 / w t$ & - & $-1 / w t$ & - & - & - & - \\
\hline 15 & $\mathrm{~T} 1$ & $A$ & 1 & $\mathrm{H}$ & II & 00 & - & $-1 / w t$ & - & $-1 / w t$ & - & - & - & $-1 / w t$ \\
\hline B6 & $\mathrm{T} 4$ & B & M & $\mathrm{L}$ & II & $\bigcirc 0$ & - & $-1 / w t$ & - & $+1 / w t$ & - & - & - & - \\
\hline B25 & T1 & $A$ & I & $\mathrm{L}$ & II & 00 & - & $-1 / w t$ & - & $-1 / w t$ & - & - & - & - \\
\hline 30 & $\mathrm{~T} 1$ & $A$ & I & $\mathrm{L}$ & II & 0 & - & - & $-1 / w t$ & - & - & - & $-1 / w t$ & - \\
\hline B4 & $\mathrm{T} 2$ & $A$ & I & $\mathrm{L}$ & II & 0 & - & $-1 / w t$ & - & $-1 / w t$ & - & - & - & - \\
\hline B8 & $\mathrm{T} 1$ & $A$ & I & $\mathrm{L}$ & II & 0 & $-1 / w t$ & $-1 / w t$ & $-1 /-1$ & $-1 /+1$ & $-2 / w t$ & $-2 / w t$ & $-1 / w t$ & $-1 / w t$ \\
\hline
\end{tabular}

paper describes the incidence of $\mathrm{MSI}+$ in gastric adenoma, comparison with our results is impossible due to the different criteria used for MSI assessment (Semba et al, 1996).

In this study, we proved that BAT-26 is a useful marker for the identification of the MSI status of gastric adenoma and carcinoma. Fifteen samples showing $\mathrm{MSI}$ in more than $40 \%$ of the 49 markers tested demonstrated alterations of BAT-26, whereas the 43 samples showing MSI in less than $40 \%$ of the markers demonstrated intact BAT-26. Similar results have already been published regarding colon carcinoma (Hoang et al, 1997) and gastric carcinoma (Zhou et al, 1998; Perucho, 1999).

The clinicopathologic characteristics of $\mathrm{MSI}+$ carcinoma reported by several researchers are: older age, antral or body location, intestinal type, Borrmann Type II, negative lymph node metastasis, and better survival. In this study, we could add that the carcinoma arising from adenoma is a subgroup that demonstrates a high frequency of the MSI+ phenotype.

Compared with a large series of colon adenomas (Boland et al, 1998), the overall MSI incidence in gastric adenoma (21\%) is 7 times higher than that of colonic adenoma (3\%). Furthermore, the TGF- $\beta$ RII gene mutation rate in the stomach $(69 \%)$ is much higher than in the colon (35\%) (Grady et al, 1998). Although this might be related to the fact that our cases consisted of larger adenomas than in nonresected cases, it also might be related to the higher risk of carcinomatous transformation in gastric adenoma than in colonic adenoma.

Our results indicate that cells do not lose the MSI characteristic during carcinomatous transformation, but gain $\mathrm{MSI}$ continuously during the gastric adenoma-carcinoma sequence, as shown in colorectal tumorigenesis (Shibata et al, 1994). In our study, nine of the adenomas demonstrated a mutation of TGF- $\beta$ RIl gene. Among them, seven adenomas showed carcinomatous transformation $(p<0.01)$. In contrast, IGFRII mutation was found in adenomas without carcinomatous transformation, and $B A X$ or $h M S H 3$ gene mutation was not more frequently seen in Type I than in Type II adenomas. This suggests that $\mathrm{MSI}+$ adenoma, especially with TGF- $\beta$ RII gene mutation, is prone to cancerous change. In addition, MSI and TGF- $\beta$ RII gene mutation are early somatic events in the gastric adenoma-carcinoma sequence. Increased cancer risk of $\mathrm{MSI}+$ adenoma in the colon has been suggested (Jacoby et al, 1995; Lothe et al, 1995), and our data support an increased risk in gastric adenoma.

In our study, the incidence of $B A X$ gene mutation was $68 \%$ in $\mathrm{MSI}+$ carcinomas, similar to the previously published data of $64 \%$ in the Western population (Yamamoto et al, 1997). In contrast, the incidence 


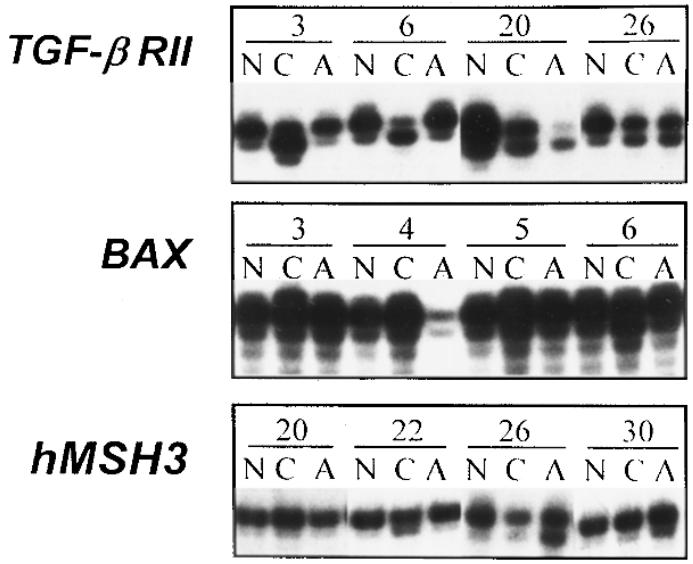

Figure 5.

Examples of frameshift mutation in MSI+ adenoma and carcinoma of the stomach. The genes are indicated at the left of each panel. Mutation was identified by the presence of bands in tumor DNA that are not present in the corresponding normal DNA. N, normal; C, carcinoma; A, adenoma. Top panel, Cases $3(\mathrm{C}), 6(\mathrm{C}), 20(\mathrm{~A})$, and $26(\mathrm{C}$ and $\mathrm{A})$ showed deletion of one nucleotide in the poly $(A)_{10}$ tract of the TGF- $\beta$ R/l gene. Middle panel, Case 3 (C) showed gain of one nucleotide, and Case $6(C)$ showed one nucleotide deletion in the poly $(\mathrm{G})_{8}$ tract of the $B A X$ gene. Bottom panel, Cases $22(\mathrm{C}), 26(\mathrm{~A})$, and $30(\mathrm{~A})$ showed deletion of one nucleotide in poly $(A)_{8}$ tract in the $h M S H 3$ gene.

of $B A X$ gene mutation is much lower in adenoma $(31 \%)$. This suggests that although $\mathrm{MSI}$ is an early change, mutations of specific genes could be accumulated during the carcinomatous transformation. In contrast to TGF- $\beta$ RII gene mutation, BAX mutation might develop during the carcinomatous transformation. We observed that $38 \%$ of $\mathrm{MSI}+$ adenomas showed $h M S H 3$ gene mutation, which is higher than the incidence in carcinomas (33\%). Our data could not prove the previous theory that $h M S H 3$ mutation increased the mutation rate of other genes with microsatellites.

In our study, two of the Type II cases showed mutations in the IGFIIR gene, but none of the Type I cases were associated with IGFIIR gene mutation. The absence of IGFIIR gene mutation in adenomaassociated carcinoma should draw our attention, but the rarity of $\mathrm{MSI}+$ cases in Type II carcinoma or adenoma prohibits drawing any conclusion.

The incidence of $\mathrm{MSI}+$ in the cases with multiple carcinomas and adenoma is higher than in the patients with single carcinoma. We also identified heterogeneity of the MSI and frameshift mutations, in which the carcinogenic process of each tumor may have diverse microsatellite alterations even under the same genetic background. In contrast, multiple synchronous gastric carcinomas without adenoma do not show a higher rate of $\mathrm{MSI}+$ (manuscript in preparation). Although several reports have shown that multiple gastric carcinomas are frequently associated with $\mathrm{MSI}+$, it remains to be proven whether this is related to the association of adenoma, or to the multiplicity itself.

In summary, our data showed that carcinomaassociated adenomas either in Type I or in Type II are frequently associated with $\mathrm{MSI}+$. Multiple synchro- nous carcinomas associated with adenoma showed an even higher frequency of $\mathrm{MSI}+$. We also proved that MSI and mutation of TGF- $\beta$ RII gene are changes that occur early in the adenoma-carcinoma sequence and that they persist after malignant transformation, whereas $B A X$ gene mutation seems to occur at a later stage. Research regarding the molecular mechanism of $\mathrm{MSI}$ in adenoma and during adenoma-carcinoma sequence is needed.

\section{Materials and Methods}

\section{DNA Extraction}

DNA from 63 cases was obtained from formalin-fixed, paraffin embedded surgical sections. To reduce the possibility of genetic abnormalities in tumor cells compromised by the presence of normal cells, the neoplastic areas were selected microscopically and microdissected from hematoxylin and eosin-stained slides. This microdissection procedure harvests more than $60 \%$ of tumor cell populations. DNA was extracted from microdissected tissues in lysis buffer (40 $\mu \mathrm{g} / \mathrm{ml}$ proteinase $\mathrm{K}, 0.5 \%$ Tween-20, $50 \mathrm{~mm}$ Tris, 25 mM EDTA, pH 8.5) and incubated for 24 to 48 hours at $55^{\circ} \mathrm{C}$. After boiling for 10 minutes to inactivate proteinase $\mathrm{K}$ and centrifugation for 5 minutes at 15,000 $\mathrm{rpm}$, the extracted DNA was stored at $-20^{\circ} \mathrm{C}$ until use.

\section{Microsatellite Markers}

Primers for the 49 microsatellite loci (containing di-, tri-, and tetranucleotide repeat sequences) were purchased from Research Genetics (MapPair, Huntsville, Alabama). The markers were D1S162, D1S237, D2S119, D2S104, D3S1274, D3S1300, D3S1766, D3S1216, D4S174, D4S1652, D5S299, APC2, D5S346, D5S409, D6S271, D6S105, D6S310, D7S507, D7S1805, D8S254, D8S555, D9S104, D9S103, D10S183, D10S109, D11S875 (MISC), D11S897, D12S95, D12S375, D13S120, D14S51, CYP19, D16S403, D16S413, TP53, D17S796, D17S786, D17S520, D17S791, D18S53, D18S34, D18S386, D19S177, D19S416, D20S66, D20S17, D21S411, D21S258, and IL2RB. Primers for the mononucleotide repeat microsatellite sequences were: BAT-26 (Hoang et al, 1997; Zhou et al, 1998), located within intron 5 of the $h M S H 2$ gene; BAT-25, located in the introns of the c-kit oncogene; poly $(A)_{10}$ tract of TGF- $\beta$ RII (Markowitz et al, 1995); poly $(\mathrm{G})_{8}$ tract of $B A X$ (Rampino et al, 1997); poly(G) $)_{8}$ tract of IGFIIR (Souza et al, 1996); and poly $(\mathrm{A})_{8}$ tract of $h M S H 3$ (Malkhosyan et al, 1996) were made according to the procedures described in previously published papers.

\section{PCR Amplification and Microsatellite Analysis}

PCR amplification with MapPair primers was performed with $5 \mathrm{pmol} / \mu \mathrm{l}$ of each primer, $1.5 \mathrm{mM} \mathrm{MgCl}_{2}$, $0.2 \mathrm{~mm}$ deoxynecleotide triphosphate, 0.5 unit Taq polymerase, $0.1 \mu \mathrm{l}\left[\alpha^{-}{ }^{32} \mathrm{P}\right] \mathrm{dCTP}\left(3,000 \mathrm{Ci} \mathrm{mmol}^{-1}\right.$, NEN, Dupoint, Boston, Massachusetts), and 1-2 $\mu \mathrm{l}$ DNA in a total volume of $10 \mu \mathrm{l}$. The PCR conditions 
Table 3. Microsatellite Instability and Mutations in Coding Mononucleotide Repeats in Multiple Gastric Carcinomas Associated with Adenoma

\begin{tabular}{|c|c|c|c|c|c|c|c|}
\hline Case & Type $^{a}$ & Lesion & $\mathrm{MSI}^{b}$ & TGF- $\beta$ RII & BAX & IGFIIR & hMSH3 \\
\hline \multirow[t]{4}{*}{ B11 } & & A & - & - & - & - & - \\
\hline & I & $\mathrm{C} 1$ & - & $-1 / w t$ & $-1 / w t$ & - & - \\
\hline & ॥ & C2 & • & $-1 / w t$ & - & - & - \\
\hline & II & C3 & 0 & - & - & - & - \\
\hline \multirow[t]{3}{*}{ B20 } & & A & - & $-1 / w t$ & - & - & - \\
\hline & I & C1 & 0 & $-1 / w t$ & $-1 / w t$ & - & $-1 / w t$ \\
\hline & ॥ & C2 & 0 & - & - & - & - \\
\hline \multirow[t]{3}{*}{ B24 } & & $A$ & 0 & $-1 / w t$ & - & - & - \\
\hline & 1 & $\mathrm{C1}$ & 0 & $-1 / w t$ & $-1 / w t$ & - & $-1 / w t$ \\
\hline & II & C2 & - & $-1 / w t$ & - & - & $-1 / w t$ \\
\hline \multirow[t]{3}{*}{30} & & A & - & - & $-1 / w t$ & - & $-1 / w t$ \\
\hline & ॥ & $\mathrm{C} 1$ & - & - & - & - & - \\
\hline & II & C2 & - & - & - & - & - \\
\hline \multirow[t]{3}{*}{ B8 } & & $A$ & 0 & $-1 / w t$ & $+1 /-1$ & $-2 / w t$ & $-1 / w t$ \\
\hline & ॥ & C1 & - & $-1 / w t$ & $-1 /+1$ & $-2 / w t$ & $-1 / w t$ \\
\hline & II & C2 & - & $-1 / w t$ & $-1 /+1$ & $-2 / w t$ & $-1 / w t$ \\
\hline \multirow[t]{3}{*}{ B12 } & & $A$ & $\bigcirc$ & - & - & - & - \\
\hline & II & $\mathrm{C} 1$ & 0 & - & - & - & - \\
\hline & II & C2 & 0 & - & - & - & - \\
\hline \multirow[t]{3}{*}{ B27 } & & $A$ & 0 & - & - & - & - \\
\hline & II & $\mathrm{C} 1$ & 0 & - & - & - & - \\
\hline & II & C2 & 0 & - & - & - & - \\
\hline \multirow[t]{4}{*}{ B28 } & & $A$ & 0 & - & - & - & - \\
\hline & ॥ & $\mathrm{C} 1$ & 0 & - & - & - & - \\
\hline & ॥ & C2 & 0 & - & - & - & - \\
\hline & II & C3 & 0 & - & - & - & - \\
\hline
\end{tabular}

${ }^{a}$ Type I and II, same as Table 1. The type denotes the relationship between adenoma and each carcinoma.

${ }^{b} \bigcirc$ and $\bullet$, same as Table 2.

were $95^{\circ} \mathrm{C}$ for 5 minutes, followed by 33 cycles $\left(94^{\circ} \mathrm{C}\right.$ for 30 seconds, $45^{\circ} \mathrm{C}$ to $58^{\circ} \mathrm{C}$ for 30 seconds, $72^{\circ} \mathrm{C}$ for 40 seconds) and a final elongation step at $72^{\circ} \mathrm{C}$ for 10 minutes. PCR products were diluted to a concentration of $1: 4$ with loading buffer, heated at $100^{\circ} \mathrm{C}$ for 5 minutes, and stored on ice until analysis. Then $1.5 \mu \mathrm{l}$ aliquots of each sample were separated on denatured $6 \%$ polyacrylamide gel. The gel was dried on a vacuum slab gel dryer at $80^{\circ} \mathrm{C}$ for $1-1.5$ hours and exposed to X-ray film at $-70^{\circ} \mathrm{C}$ for $12-72$ hours.

To detect frameshift mutations in the coding regions, the reaction involved 32 cycles at $94^{\circ} \mathrm{C}$ for 1 minute, at $53^{\circ} \mathrm{C}$ to $60^{\circ} \mathrm{C}$ for 1 minute, and at $72^{\circ} \mathrm{C}$ for 1 minute, using $3.7 \times 10^{4} \mathrm{~Bq}$ of ${ }^{32} \mathrm{P}$-dCTP in $10 \mu \mathrm{l}$ of reaction mixture. The subsequent procedures were the same as for the MSI analysis.

\section{Statistical Analysis}

The association between MSI and the clinicopathologic profiles was analyzed using $\chi^{2}$ test or Fisher's exact test. Statistical significance was defined as $p<$ 0.05 .

\section{References}

Arnheim N and Shibata D (1997). DNA mismatch repair in mammals: Role in disease and meiosis. Curr Opin Genet Dev 7:364-370.
Boland CR, Thibodeau SN, Hamilton SR, Sidransky D, Eshleman JR, Burt RW, Meltzer SJ, Rodriguez-Bigas MA, Fodde R, Ranzani GN, and Strivastava S (1998). A National Cancer Institute workshop on microsatellite instability for cancer detection and familial predisposition: Development of international criteria for the determination of microsatellite instability in colorectal cancer. Cancer Res 58:5248-5257.

Chung YJ, Park SW, Song JM, Lee KY, Seo EJ, Choi SW, and Rhyu MG (1997). Evidence of genetic progression in human gastric carcinomas with microsatellite instability. Oncogene 15:1719-1726.

Chung YJ, Song JM, Lee JY, Jung YT, Seo EJ, Choi SW, and Rhyu MG (1996). Microsatellite instability-associated preferentially with the intestinal type of primary gastric carcinomas in a high-risk population. Cancer Res 56:4662-4665.

Grady WM, Rajput A, Myeroff L, Liu DF, Kwon K, Willis J, and Markowitz S (1998). Mutation of the type II transforming growth factor-beta receptor is coincident with the transformation of human colon adenomas to malignant carcinomas. Cancer Res 58:3101-3104.

Halling KC, Harper J, Moskaluk CA, Thibodeau SN, Petroni GR, Yustein AS, Tosi P, Minacci C, Roviello F, Piva P, Hamilton SR, Jackson CE, and Powell SM (1999). Origin of microsatellite instability in gastric cancer. Am J Pathol 155: 205-211.

Hoang J, Cottu PH, Thuille B, Salmon RJ, Thomas G, and Hamelin R (1997). BAT-26, an indicator of the replication error phenotype in colorectal cancers and cell lines. Cancer Res 57:300-303. 
Jacoby RF, Marshall DJ, Kailas S, Schlack S, Harms B, and Love R (1995). Genetic instability associated with adenoma to carcinoma progression in hereditary nonpolyposis colon cancer. Gastroenterology 109:73-82.

Kamiya T, Morishita T, Asakura H, Miura S, Munakata Y, and Tsuchiya M (1982). Long-term follow-up on gastric adenoma and its relation to gastric protruded carcinoma. Cancer 50:2496-2503.

Kane MF, Loda M, Gaida GM, Lipman J, Mishra R, Goldman H, Jessup JM, and Kolodner R (1997). Methylation of the hMLH1 promoter correlates with lack of expression of hMLH1 in sporadic colon tumors and mismatch repairdefective human tumor cell lines. Cancer Res 57:808-811.

Kang GH, Yoon GS, Lee HK, Kwon YM, and Ro JY (1999). Clinicopathologic characteristics of replication error-positive gastric carcinoma. Mod Pathol 12:15-20.

Lauren P (1965). The two histological main types of gastric carcinoma; diffuse and so-called intestinal-type carcinoma: An attempt at a histo-clinical classification. Acta Pathol Microbiol Scand 64:31-49.

Leung SY, Yuen ST, Chung LP, Chu KM, Chan AS, and Ho JC (1999). hMLH1 promoter methylation and lack of hMLH1 expression in sporadic gastric carcinomas with highfrequency microsatellite instability. Cancer Res 59:159-164.

Lothe RA, Anderson SN, Hofstad B, Meling GI, Peltomaki P, Heim S, Brogger A, Vatn M, Rognum TO, and Borresen AL (1995). Deletion of $1 p$ loci and microsatellite instability in colorectal polyps. Genes Chromosomes Cancer 14:182-188.

Malkhosyan S, Rampino N, Yamamoto $\mathrm{H}$, and Perucho $\mathrm{M}$ (1996). Frameshift mutator mutations. Nature 382:499-500.

Markowitz S, Wang J, Myeroff L, Parsons R, Sun L, Lutterbaugh J, Fan RS, Zborowska E, Kinzler KW, Vogelstein B, Brattain M, and Willson JKV (1995). Inactivation of the type II TGF receptor in colon cancer cells with microsatellite instability. Science 268:1336-1338.

Ming SC and Goldman H (1965). Gastric polyps: A histogenetic classification and its relation to carcinoma. Cancer 18:721-726.

Ming SC (1977). Gastric carcinoma: A pathobiological classification. Cancer 39:2475-2485.

Myeroff LL, Parsons R, Kim SJ, Hedrick L, Cho KR, Orth K, Mathis M, Kinzler KW, Lutterbaugh J, Park K, Bang YJ, Lee HY, Park JG, Lynch HT, Roberts AB, Vogelstein B, and Markowitz SD (1995). A transforming growth factor A receptor type II gene mutation common in colon and gastric but rare in endometrial cancers with microsatellite instability. Cancer Res 55:5545-5547.

Ouyang H, Shiwaku HO, Hagiwara H, Miura K, Abe T, Kato Y, Ohtani H, Shiiba K, Souza RF, Meltzer SJ, and Horii A (1997). The insulin-like growth factor II receptor gene is mutated in genetically unstable cancers of the endometrium, stomach, and colorectum. Cancer Res 57:1851-1854.
Perucho M (1999). Correspondence re: C. R. Boland et al., A National Cancer Institute workshop on microsatellite instability for cancer detection and familial predisposition: Development of international criteria for the determination of microsatellite instability in colorectal cancer (Letter). Cancer Res 59:249-256.

Rampino N, Yamamoto H, lonov Y, Li Y, Sawai H, Reed JC, and Perucho M (1997). Somatic frameshift mutations in the $B A X$ gene in colon cancers of the microsatellite mutator phenotype. Science 275:967-969.

Semba S, Yokozaki H, Yamamoto S, Yasui W, and Tahara E (1996). Microsatellite instability in precancerous lesions and adenocarcinomas of the stomach. Cancer 77:1620-1627.

Shibata D, Peinado MA, lonov Y, Malkhosyan W, and Perucho $M$ (1994). Genomic instability in repeated sequence is an early somatic event in colorectal tumorigenesis that persists after transformation. Nat Genet 6:273-281.

Souza RF, Appel R, Yin J, Wang S, Smolinski KN, Abraham JM, Zou TT, Shi YQ, Lei J, Cottrell J, Cymes K, Biden K, Simms L, Young J, and Meltzer SJ (1996). Microsatellite instability in the insulin-like growth factor II receptor gene in gastrointestinal tumors. Nat Genet 14:255-257.

Tahara E (1995). Molecular biology of gastric cancer. World J Surg 19:484-490.

UICC (1997). Stomach. In Sobin LH and Wittekind C, editors. TNM classification of malignant tumours, $5^{\text {th }}$ ed. New York: Wiley-Liss, 59-62.

Watanabe H, Jass JR, and Sobin LH (1990). Histological typing of oesophageal and gastric tumors. In World Health Organization International Histological Classification of tumors, $2^{\text {nd }}$ ed. Berlin: Springer.

Yamamoto H, Sawai H, and Perucho M (1997). Frameshift somatic mutations in gastrointestinal cancer of the microsatellite mutator phenotype. Cancer Res 57:4420-4426.

Yamamoto $\mathrm{H}$, Itoh $\mathrm{F}$, Fukushima $\mathrm{H}$, Adachi $\mathrm{Y}$, Itoh $\mathrm{H}$, Hinoda $\mathrm{Y}$, and Imai $\mathrm{K}$ (1999). Frequent Bax frameshift mutations in gastric cancer with high but not low microsatellite instability. J Exp Clin Cancer Res 18:103-106.

Zhou XP, Hoang JM, Li YJ, Seruca R, Carneiro F, SobrinhoSimoes M, Lothe RA, Gleeson CM, Russell SE, Muzeau F, Flejou JF, Hoang-Xuan K, Lidereau R, Thomas G, and Hamelin R (1998). Determination of the replication error phenotype in human tumors without the requirement for matching normal DNA by analysis of mononucleotide repeat microsatellites. Genes, Chromosomes Cancer 21:101-107. 